\title{
Terminase Large Subunit Provides a New Drug Target for Herpesvirus Treatment
}

\author{
Linlin Yang ${ }^{1,2,3, \dagger}$, Qiao Yang ${ }^{1,2,3, *, \dagger}$, Mingshu Wang ${ }^{1,2,3}$, Renyong Jia ${ }^{1,2,3}$, Shun Chen $1,2,3$ (D), \\ Dekang Zhu 1,2,3 ${ }^{10}$, Mafeng Liu 1,2,3, Ying Wu 1,2,3, Xinxin Zhao 1,2,3, Shaqiu Zhang ${ }^{1,2,3}$, \\ Yunya Liu 1,2,3, Yanling Yu 1,2,3, Ling Zhang ${ }^{1,2,3}$, Xiaoyue Chen ${ }^{2,3}$ and Anchun Cheng ${ }^{1,2,3, *(D)}$ \\ 1 Institute of Preventive Veterinary Medicine, Sichuan Agricultural University, Chengdu 611130, \\ Sichuan, China; qzylj_yll@163.com (L.Y.); mshwang@163.com (M.W.); cqrc_jry@163.com (R.J.); \\ shunchen@sicau.edu.cn (S.C.); zdk24@sicau.edu.cn (D.Z.); liumafengra@163.com (M.L.); \\ yingzi_no1@126.com (Y.W.); xxinzhao@sicau.edu.cn (X.Z.); shaqiu86@hotmail.com (S.Z.); \\ yunnyaaliu@163.com (Y.L.); yanling3525@163.com (Y.Y.); z197451@126.com (L.Z.); chenxy_24@sina.cn (X.C.) \\ 2 Research Center of Avian Diseases, College of Veterinary Medicine, Sichuan Agricultural University, \\ Chengdu 611130, Sichuan, China \\ 3 Key Laboratory of Animal Disease and Human Health of Sichuan Province, Chengdu 611130, \\ Sichuan, China \\ * Correspondence: yangqiao@sicau.edu.cn (Q.Y.); chenganchun@vip.163.com (A.C.); \\ Tel.: +86-28-86291776 (Q.Y. \& A.C.) \\ + These authors contributed equally to this work.
}

Received: 3 December 2018; Accepted: 27 February 2019; Published: 5 March 2019

\begin{abstract}
Herpesvirus infection is an orderly, regulated process. Among these viruses, the encapsidation of viral DNA is a noteworthy link; the entire process requires a powered motor that binds to viral DNA and carries it into the preformed capsid. Studies have shown that this power motor is a complex composed of a large subunit, a small subunit, and a third subunit, which are collectively known as terminase. The terminase large subunit is highly conserved in herpesvirus. It mainly includes two domains: the C-terminal nuclease domain, which cuts the viral concatemeric DNA into a monomeric genome, and the N-terminal ATPase domain, which hydrolyzes ATP to provide energy for the genome cutting and transfer activities. Because this process is not present in eukaryotic cells, it provides a reliable theoretical basis for the development of safe and effective anti-herpesvirus drugs. This article reviews the genetic characteristics, protein structure, and function of the herpesvirus terminase large subunit, as well as the antiviral drugs that target the terminase large subunit. We hope to provide a theoretical basis for the prevention and treatment of herpesvirus.
\end{abstract}

Keywords: herpesvirus; terminase large subunit; ATPase; nuclease; DNA packaging; antiviral drug

\section{Introduction}

The members of Herpesviridae are double-stranded DNA (dsDNA) viruses. According to the International Committee on Taxonomy of Viruses (ICTV), in April 2018 [1], the family Herpesviridae was divided into three subfamilies (Alphaherpesvirinae, Betaherpesvirinae, and Gammaherpesvirinae) and an unassigned genus thought to have diverged from a common ancestor 400 million years ago [2,3].

Herpesvirus particles mainly have four components [4-6]: the relatively large linear DNA genomes encased within an icosahedral capsid wrapped in a protein layer called the tegument, which is encased in a lipid bilayer membrane called the envelope. In addition, the tegument contains both viral proteins and viral mRNAs. This whole particle is known as a virion, which possess infectivity. 
When the herpesvirus is in the process of the lytic replication cycle [7], viral membrane glycoproteins mediate the fusion of the viral envelope with the cell membrane [8,9]. Subsequently, the viral nucleocapsid is released into the cytoplasm, and viral DNA enters the nucleus through nuclear pores [10]. The virus carries out DNA replication, viral gene transcription, capsid assembly, and DNA packaging within the nucleus. Finally, the DNA-containing nucleocapsids pass through the nuclear membrane and the Golgi inclusions in turn to obtain the mature envelope protein and intact outer membrane layer [11]. Mature virus particles are released from the cytoplasm through exocytosis [12].

In HSV-1, the UL15 gene encodes the terminase large subunit, pUL15, which is a nonstructural protein involved in viral DNA cleavage and packaging, along with at least six other proteins (pUL6, pUL17, pUL25, pUL28, pUL32, and pUL33) during virus infection. When any gene is deleted or has a nonfunctional mutation, an accumulation of viral concatemeric DNA and immature capsids will occur within the infected cell nucleus [13-19]. pUL15, pUL28, and pUL33 are believed to have terminase complex functions that cleave the head-to-tail linked viral concatemeric DNA at a precise location to release unit-length genomes and package the DNA into preformed capsids [20-23]. This mechanism exists in prokaryotic and eukaryotic dsDNA viruses, such as bacteriophages and herpesviruses [24-28].

\section{Genome Cleavage and Packaging of the Herpesvirus}

In the lytic infection course of herpesvirus, three types of capsid can be separated by sucrose density gradient centrifugation [29-31]. A capsids are hollow shells that release the scaffold protein and do not have DNA. These capsids are usually caused by DNA packaging failure. B capsids are angularized capsids that still have the scaffold protein but are not wrapped with DNA and are thought to mature without ever encountering the DNA encapsidation machinery. $\mathrm{C}$ capsids are mature capsids that encapsulate the DNA and release the scaffolding. In addition, the procapsid, a precursor form of the A, B, and C capsids, exists in herpesvirus infection. The procapsid is a fragile, largely spherical shell that contains an inner scaffold. The virions first form a procapsid with a scaffold structure in the nucleus. When the DNA is packaged, the scaffold structure gradually disintegrates, and a mature $\mathrm{C}$ capsid with a capsule is eventually formed [32,33].

During the viral DNA packaging process, the three terminase subunits form a complex in the cytoplasm and then enter the nucleus to perform the functions [34,35]. pUL15 and its homologs are generally considered to be terminase large subunits that function as nuclease to cleave the viral concatemeric DNA [22]. The terminase small subunit, pUL28 and its homologs, plays a role in recognizing and binding to the pac elements (pac1 and pac2) at the end of the free viral genome [36]. The third subunit, pUL33 and its homologs, interacts with the small subunit and enhances the interaction between the large and small subunits. The third subunit is also necessary for releasing individual genomes from viral concatemeric DNA [37]. The predominant model of herpesvirus DNA packaging proposes that the terminase complex binds to the unique portal vertex of procapsids, and the genome is transferred through the portal ring into the capsid in an ATP-dependent manner [13,38-41]. When a unit-length genome is packaged into the capsid, the nuclease activity of the large subunit is reactivated and cleaves the genome again. The packaging process of the viral genome is thus completed [42,43], and the terminase complex is able to act in additional rounds of cleavage and packaging [41,44-46] (Figure 1). 


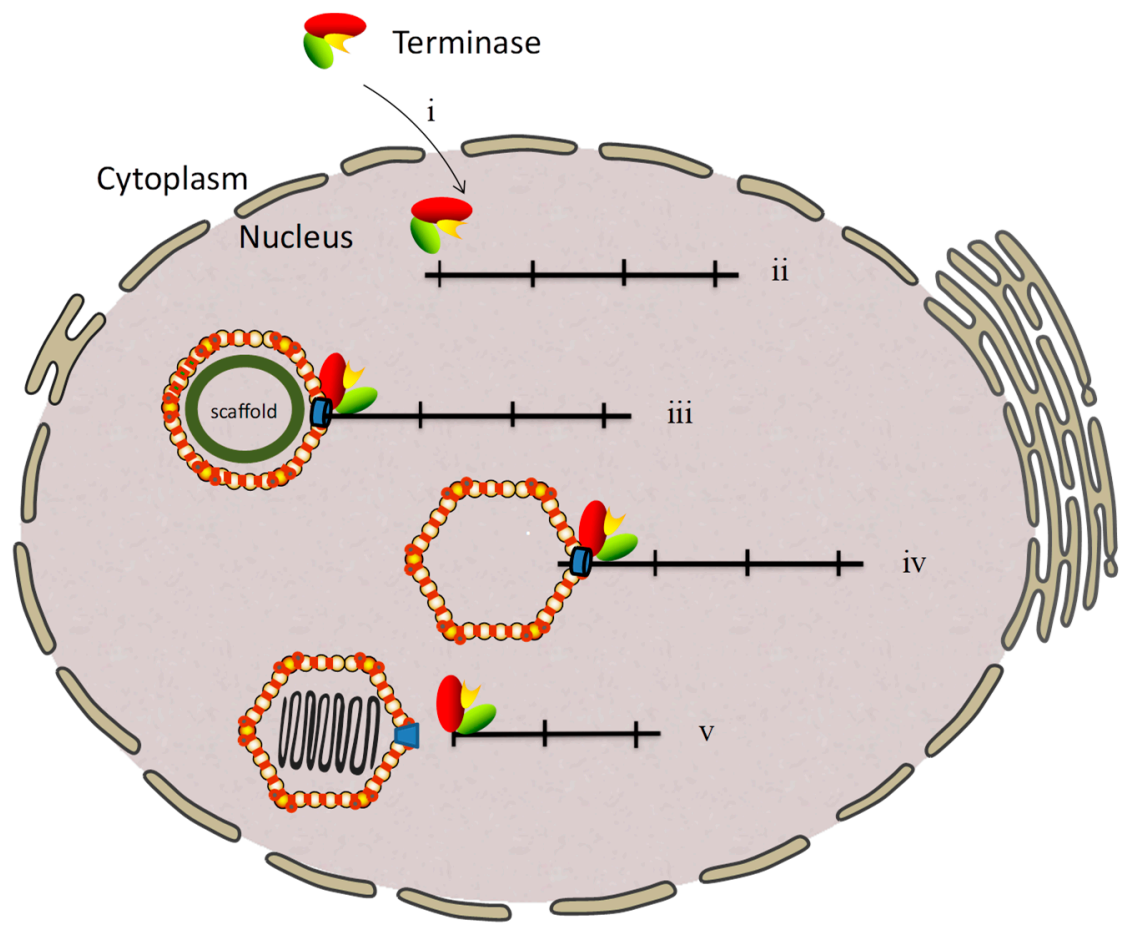

Figure 1. Herpesvirus genome cleavage/packaging. (i) Translocation of the terminase complex into the nucleus; (ii) viral DNA replication forms head-to-tail linked viral concatemeric DNA; (iii) terminase specifically binds the pac site, recruits the empty capsid, and cleaves the double-stranded DNA; (iv) translocation of a unit-length genome into the capsid; and (v) the DNA packaging process is completed by activating the nuclease activity to cut the other end of the individual genome.

\section{Characteristics of the Terminase Large Subunit Gene}

\subsection{Terminase Large Subunit Coding by a Splicing Gene}

The terminase large subunit of herpesvirus is a highly conserved gene that is referred to by different names in different viruses, such as UL15 in herpes simplex virus 1 (HSV-1), UL89 in human cytomegalovirus (HCMV), and BGRF1/BDRF1 in Epstein-Barr virus (EBV). The terminase large subunit gene is a unique spliced gene in herpesviruses and mainly consists of two exons with a different number of introns. In the $\alpha$-herpesvirus, the intron generally includes two genes. However, in $\beta$ - and $\gamma$-herpesvirus, the intron generally contains four to five genes (Table 1).

In HSV-1, the terminase large subunit gene usually has two transcripts which are translated into proteins: the full-length protein and the N-terminal truncated protein, known as pUL15 and pUL15.5. Previous studies have shown that the pUL15.5 cannot be detected specifically in any capsid form, whereas the pUL15 is detected predominantly in B capsids and at much lower levels in C capsids and virions $[46,47]$. In addition, the truncated protein pUL15.5 is not required for viral replication; however, the absence or mutation of full-length UL15 has serious effects on the production of virions $[22,35,48]$. The Baines lab has shown that there are several truncated forms (80 and $79 \mathrm{kDa})$ of pUL15 that are found at purified capsids along with the full-length $(83 \mathrm{kDa})$ pUL15. This is important, since they claim that these truncated proteins are the result of proteolytic cleavage which is required for maturation of the viral genome [49]. Therefore, this article focuses on the full-length protein of the terminase large subunit. 
Table 1. Features of herpesvirus UL15 gene and homologs.

\begin{tabular}{|c|c|c|c|c|c|c|}
\hline Subfamily & Virus Name & Abbreviation & $\begin{array}{c}\text { GenBank } \\
\text { Accession } \\
\text { Number }\end{array}$ & $\begin{array}{l}\text { Coding } \\
\text { Region }\end{array}$ & Exon/Intron & $\begin{array}{c}\text { Number of } \\
\text { Amino } \\
\text { Acids }\end{array}$ \\
\hline \multirow{9}{*}{ Aphaherpesvirus } & Varicella-zoster virus & VZV & NP_040165.1 & ORF42 & $2 / 2$ & 747 \\
\hline & Macacine alphaherpesvirus 1 & MaHV1 & ARS02909.1 & UL15 & $2 / 2$ & 738 \\
\hline & $\begin{array}{c}\text { Cercopithecine } \\
\text { alphaherpesvirus } 2\end{array}$ & $\mathrm{CeHV}-2$ & YP_164457.1 & UL15 & $2 / 2$ & 735 \\
\hline & Felid alphaherpesvirus 1 & FHV-1 & YP_003331564.1 & UL15 & $2 / 2$ & 734 \\
\hline & Suid alphaherpesvirus 1 & SuHV-1 & YP_068358.1 & UL15 & $2 / 2$ & 735 \\
\hline & Bovine alphaherpesvirus 5 & BoHV-5 & YP_003662508.1 & UL15 & $2 / 2$ & 737 \\
\hline & Bovine alphaherpesvirus 1 & BoHV-1 & APW77369.1 & UL15 & $2 / 2$ & 735 \\
\hline & Equid alphaherpesvirus 4 & EHV-4 & NP_045262.1 & ORF44 & $2 / 2$ & 734 \\
\hline & Equid alphaherpesvirus 1 & EHV-1 & BAM $\bar{M} 75895.1$ & ORF44 & $2 / 2$ & 734 \\
\hline \multirow{3}{*}{ Betaherpesvirinae } & Murid betaherpesvirus 1 & MuHV-1 & CCE56594.1 & M89 & $2 / 5$ & 678 \\
\hline & Human betaherpesvirus $6 \mathrm{~A}$ & HHV-6A & APO38446.1 & U60 & $2 / 4$ & 666 \\
\hline & Macacine betaherpesvirus 3 & MaHV-3 & AAT07420.1 & grh124 & $2 / 5$ & 671 \\
\hline \multirow{4}{*}{ Gammaherpesvirinae } & Epstein-Barr virus & EBV & YP_401690.1 & BGRF1/BDRF1 & $2 / 4$ & 690 \\
\hline & Bovine gammaherpesvirus 4 & BoHV-4 & AEL29773.1 & ORF29 & $2 / 4$ & 682 \\
\hline & Murid gammaherpesvirus 4 & MuHV-4 & AAF19294.1 & 29 & $2 / 4$ & 679 \\
\hline & Equid gammaherpesvirus 2 & EhV-2 & NP_042630.2 & ORF29 & $2 / 4$ & 686 \\
\hline
\end{tabular}

\subsection{Evolutionary Analysis and Sequence Alignment of the Terminase Large Subunit}

To build a phylogenetic tree of the terminase large subunit, we screened 21 pUL15s and their homologs from each herpesvirus subfamily. In addition, two bacteriophage proteins, T4 Gp17 and Sf21 Gp161, were selected as outgroups for the construction of phylogenetic trees, which have been shown to be homologous to herpesvirus pUL15 (Figure 2, Table 1). The phylogenetic tree based on pUL15s was mainly divided into three subfamilies: the $\alpha-, \beta$-, and $\gamma$-herpesvirus subfamilies, which are consistent with the ICTV-approved virus classification. The results showed that pUL15 may have evolved during the evolution of the species. There is a common evolutionary ancestor of subfamily pUL15s. The study found that pUL15 is a highly conserved protein among the herpesvirus family, which implies the functional significance of this protein. In addition, we could see that the phylogenetic relationship between phage and herpesvirus pUL15 is distant. However, studies have found that they are structurally similar and have the same function [50-52]. Therefore, some viruses were chosen from each herpesvirus subfamily and bacteriophage as representatives, and amino acid sequence comparison analysis of pUL15 and its homologs was performed (Figure 3).

As shown in Figure 3, two domains with enzymatic activity, the ATPase and nuclease activity domains, are present in pUL15 and its homologs. Two conserved motifs, Walker A and Walker B, were found in the amino acid sequences of the terminase large subunit proteins in herpesvirus and bacteriophages, and the two conserved motifs are the first to be found in the ATPase domain [25,53-55]. Another representative conserved $\mathrm{C}$ motif of ATPase has also been found in the amino acid sequences of pUL15 and its homologs. As shown above, pUL15 and its homologs may be involved in ATP hydrolysis. There is also a conserved triplet residue in pUL15s and their homologs, Asp-Glu-Asp, which is similar in amino acid sequence position and protein spatial structure. Previous studies have shown that conserved residues are also present in the nuclease domain of the RNase H structure [56] (Table 2, Figure 3). Mutagenesis studies confirmed that the catalytic motif is essential for enzymatic activity [51,57]. 


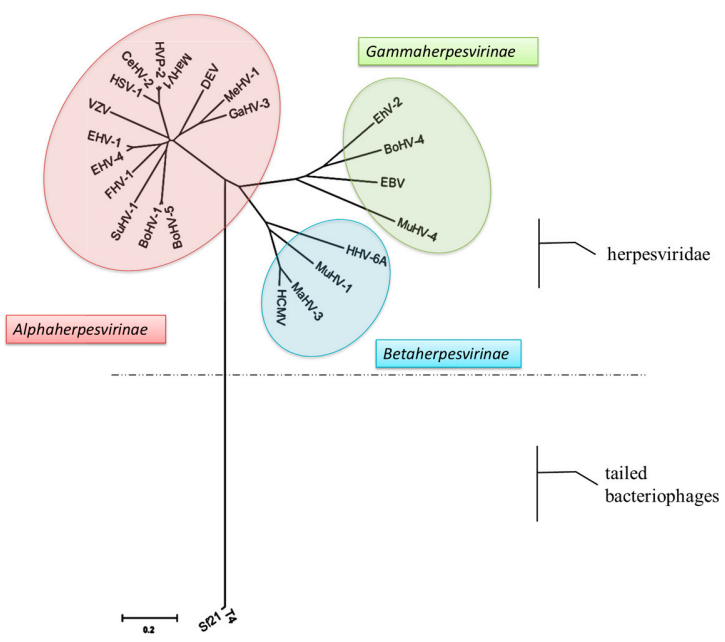

Figure 2. Phylogenetic tree based on the pUL15s sequence of 21 herpesviruses and 2 bacteriophages. The phylogenetic tree was constructed using MAGE7. The pink color represents the $\alpha$-herpesvirus subfamily, the blue represents the $\beta$-herpesvirus subfamily, and the green represents the $\gamma$-herpesvirus subfamily. The dotted line above represents the herpesvirus family virus, and below the dotted line represents the phage. The 0.2 below the evolutionary tree represents the evolutionary distance.

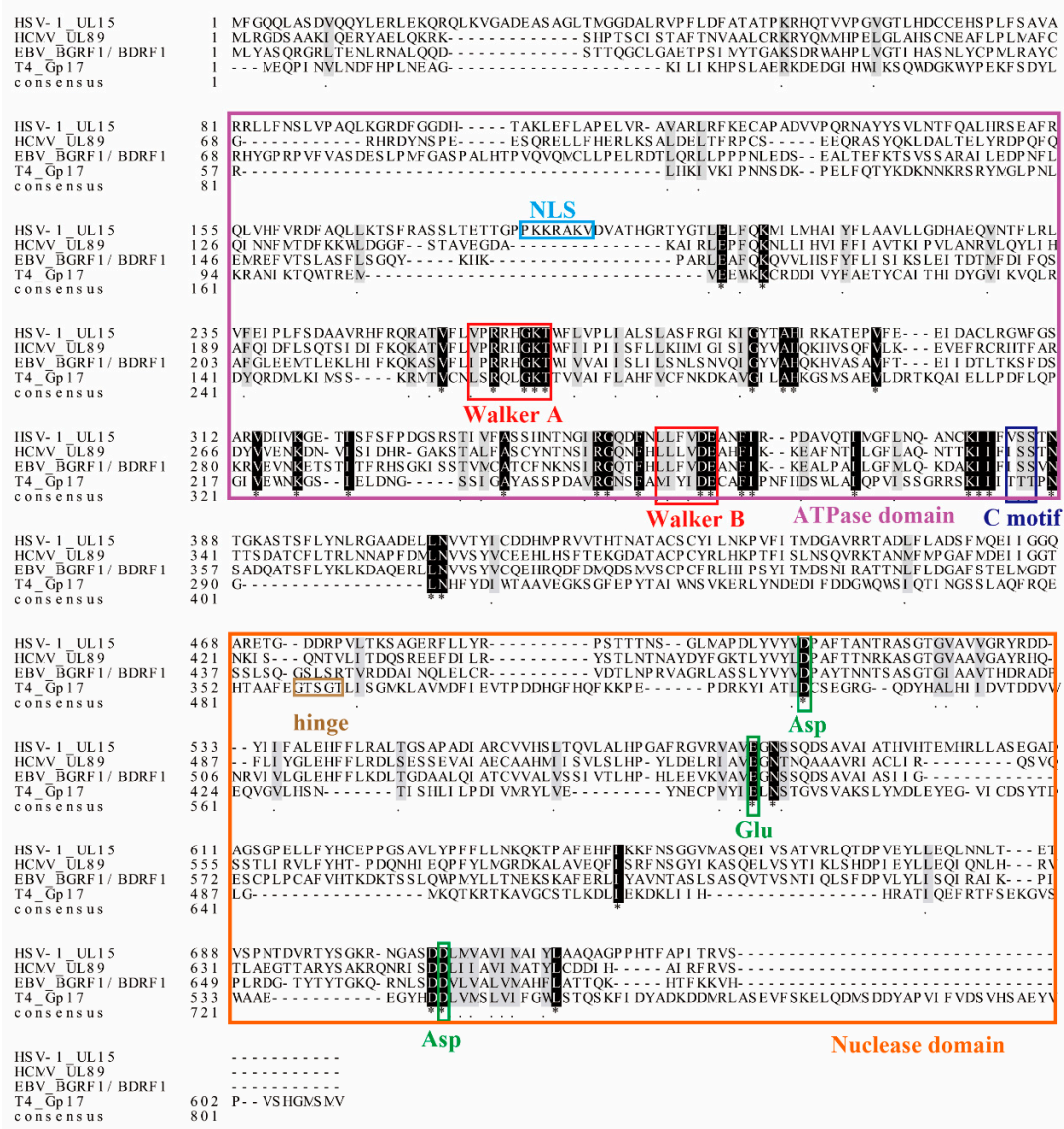

Figure 3. Sequence analysis and functional site comparison of pUL15 and homologs of different subfamilies. The alignment was completed by using MEGA7 and ClustalX2. The purple box represents the amino acid sequence of the N-terminal pUL15 and homologs ATPase activity domain; light blue box represents HSV-1 pUL15 nuclear localization signal (NLS); red box represents the Walker motif; dark blue box represents the C motif; orange box represents pUL15 C-terminal nuclease domain; brown box represents bacteriophage T4 Gp17 Hinge sequence; green box represents the catalytic triplet Asp-Glu-Asp motif. The * means that the amino acids at this site are identical. 
Table 2. Catalytic site of nuclease activity in pUL15 and homologs.

\begin{tabular}{ccccc}
\hline $\begin{array}{c}\text { Active Sites of } \\
\text { Catalytic Domain }\end{array}$ & HSV-1 pUL15 & HCMV pUL89 & $\begin{array}{c}\text { EBV } \\
\text { BGRF1/BDRF1 }\end{array}$ & T4 Gp17 \\
\hline Asp & 509 & 463 & 479 & 401 \\
Glu & 581 & 534 & 555 & 458 \\
Asp & 707 & 651 & 667 & 542 \\
\hline
\end{tabular}

\section{Structural and Functional Features of the Terminase Large Subunit}

\subsection{Overall Structure of the Terminase Large Subunit}

Previous studies have shown that HSV-1 pUL15 is a catalytic element of the terminase complex and mainly consists of two domains: the N-terminal ATPase domain and the C-terminal nuclease domain [50] (Figure 4A). According to previous reports [58], there is significant flexibility between the ATPase and nuclease domains.

In HSV-1, the folding of the pUL15 C-terminal domain structure (pUL15C) is similar to that of $\mathrm{RNaseH}$, integrases, and topoisomerases, indicating that the catalytic mode of pUL15 is similar to the metal-ion-mediated catalysis of them [50,56]. Each pUL15C molecule contains a seven-stranded $\beta$-sheet and six $\alpha$-helical regions, with parallel and antiparallel strands sandwiched between the helices. The core folds in HSV-1 pUL15C, HCMV pUL89C, RNase H, T4 phage Gp17, and other proteins show a conserved five-stranded mixed sheet arranged as $\beta 5-\beta 4-\beta 1-\beta 2-\beta 3$, which contains four parallel strands and one antiparallel $\beta 2$. Negative and positive charges cover the surface of pUL15C [50]. The active site groove has a large negative charge, which is consistent with the recruitment of metal ions for DNA binding and cleavage. In addition, some loops are close to putative nuclease active sites that may interact with DNA substrates, meaning that these loops are flexible and may undergo configurational changes when combined with DNA [50]. A previous study revealed that the C-terminus of the large subunit of the terminase in herpesviruses and phages is mobile and can interact with other components of DNA packaging [50,59-61].

The spatial structures of HSV-1 pUL15C and HCMV pUL89C are highly similar, but partial structural elements in pUL15C are different from those in HCMV pUL89 [50,57] (Figure 4). (1) X-ray analysis of the protein crystal structure revealed that the UL15 C-terminus has three protein molecules in the asymmetric unit, but the UL89 C-terminus has four protein molecules. (2) The surface loops L1 and L2 are visible in HSV-1 pUL15C but are invisible in HCMV pUL89C. (3) There is a 31- $\AA$ distance between the C- $\alpha$ atom of C-terminal residues of HSV-1 pUL15C and HCMV pUL89C due to the conformational difference between the HSV-1 pUL15C amino acid residues Ala720 to Ile732 and the HCMV pUL89 C-terminal domain. Comparative structural analysis revealed that the two structural elements, $\beta 5$ and $\beta 7$, encoded by the two regions Tyr620 to Phe633 and Ile661 to Thr665 in pUL15C exhibited differences in cell RNase $\mathrm{H} 1$ and phage homologs. The $\beta 5$ structure forms an extended surface hairpin structure in pUL15C, but this structure is absent in RNase H1 and SPP1 G2P. Like the $\beta 5$, the $\beta 7$ structure is also absent in RNase H1, SPP1 G2P, and P22 gp2 [62-64].

Currently, the study of the N-terminal domain of the large subunit of the terminal enzyme mainly concentrates on the phage. The ATPase domain of the T4 terminase large subunit Gp17 is composed of two subdomains: large subdomain I and small subdomain II, which form a groove that binds to ATP (Figure 4D,E). The subdomain I structure contains a typical Rossmann fold, which contains six parallel $\beta$-folded chains surrounded by $\alpha$-helices-a classical structural motif in nucleotide-binding proteins [65-67]. 

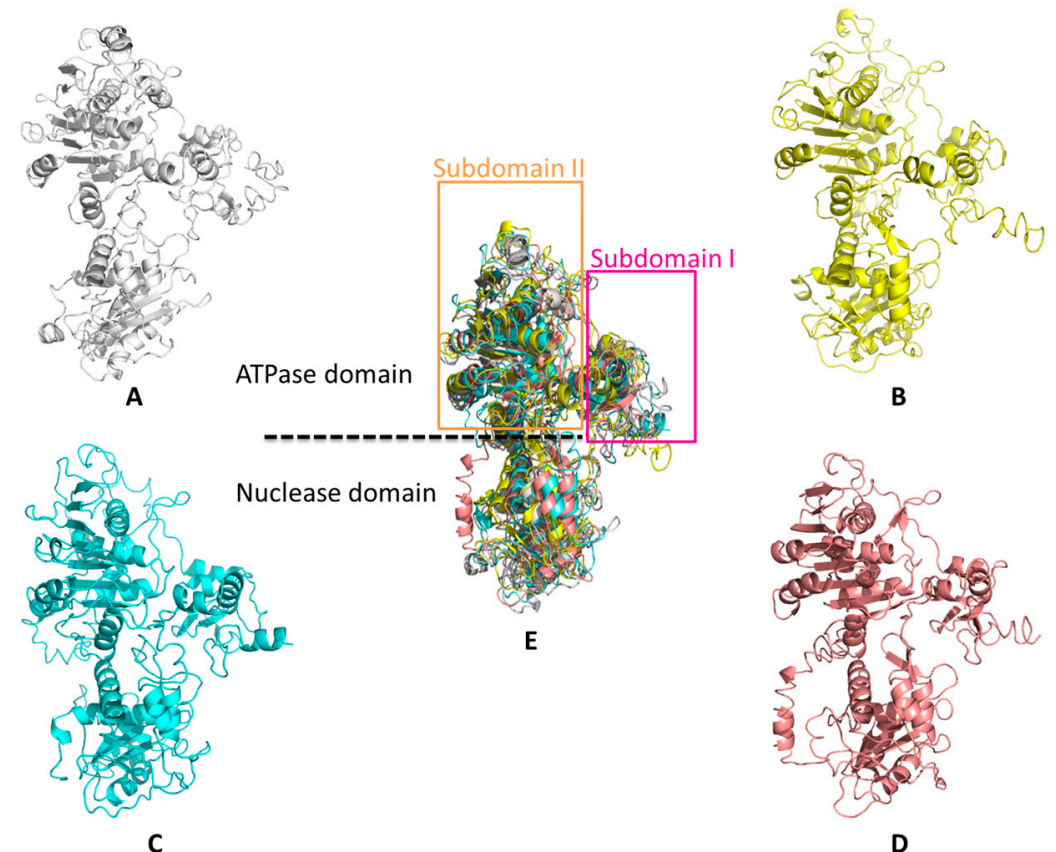

B

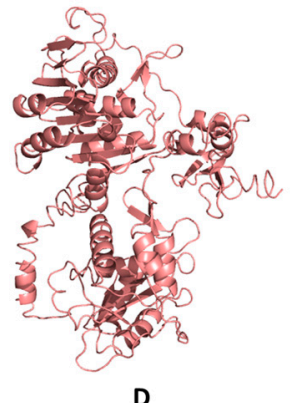

Figure 4. Structural comparison of pUL15 of the four viruses using PyMOL. (A-D) The pUL15 structure of HSV-1 UL15, HCMV UL89, EBV BGRF1/BDRF1, and T4 Gp17 are represented in gray, yellow, light blue, and pink, respectively. (E) Superposition of the HSV-1 UL15C nuclease with large terminase nuclease from HCMV, EBV, and T4. The N-terminal region of the large subunit of the terminase is mainly above the dotted line and mainly contains the ATPase domain. The C-terminal region of the large subunit of the terminase is mainly below the dotted line and mainly contains a nuclease domain.

\subsection{ATPase Functions of the Terminase Large Subunit}

The amino acid sequence of HSV-1 pUL15 shares homology with the large subunit of the terminase complex of the family Herpesviridae and bacteriophage, particularly with respect to the two nucleotide-binding motifs in the ATP-binding domain known as Walker A and Walker B. The Walker motifs of pUL15 and its homolog are very similar in spatial structure, position in the amino acid sequence, and distance between the two motifs (Figure 3) $[48,68]$. The classic Walker A and Walker B sequences are G/A-4X-G-K-T/S and G-3X-L-4Z-D-E, respectively. " $\mathrm{X}$ " can be any amino acid, and "Z" represents a hydrophobic amino acid [69]. The Walker A can bind to ATP to cause a change in the conformation of the terminase subunit, resulting in tighter binding between DNA and ATP. These two motifs are studied more thoroughly in the phage. Take the Walker motif study of the phage as an example. In Walker A, the Gly residue is a key site for binding to ATP that also has the function of stabilizing Mg-ADP, and its inactivating mutation will lead to the reduction or even loss of enzyme activity. The Glu residue in the Walker B motif is the catalytic site of the ATPase, and its mutation will result in a complete loss of DNA packaging activity $[53,54,70]$.

pUL15 and its homolog also have a C motif that is one of the typical features of ATPase. The C motif is an ATPase-coupled motif consisting of three amino acid residues, and the third amino acid is the most conserved and is usually a Thr or Ser residue [70] (Figure 3). The C motif mutant of T4 Gp17 is characterized by a loss of nuclease and ATPase activity and resistance to DNA translocation in vitro [70].

The amino acid sequence analysis reveals that herpesvirus terminase large subunit is a candidate for coupling the energy from ATP hydrolysis to DNA translocation, as demonstrated by the function of the large subunit of the phage T4 Gp17 [55,70,71]. The difference between the two homologs is that T4 Gp17 has weaker ATPase activity, and this activity can be activated by more than 50 -fold in the presence of the terminase small subunit Gp16 [71,72]. The ATPase domain of Gp17 also displays DNA 
binding functions, which may be related to its involvement in the packaging process of DNA [73]. However, in HCMV, although the pUL89 has the Walker A and Walker B motifs, it does not exhibit any ATPase activity; interestingly, the ATPase activity of pUL56 has been reported [74,75]. In addition, pUL89 can enhance the ATPase activity of pUL56 $[75,76]$.

\subsection{Nuclease Functions of the Terminase Large Subunit}

Biochemical data and structure analysis of a C-terminal domain of the HCMV terminase large subunit pUL89 revealed that pUL89 carries an RNase H-like nuclease activity that may be important for the cleavage of viral concatemeric DNA into monosomic genomes [57]. The nuclease activity of the protein is activated when the DNA packaging process begins and ends, and then pUL89 binds and cleaves the long concatemeric DNA into unit-length genomes for encapsidation [57]. This activity is enhanced when pUL56 is present [75]. In HSV-1, the viral DNA cannot be normally cleaved and packaged when the conserved amino acids are mutated at positions Asp509, Glu581, and Asp707 in the pUL15-C nuclease active site, corresponding to residues Asp463, Glu534, and Asp651 in HCMV pUL89C; Asp479, Glu555, and Asp667 in EBV BGRF1/BDRF1; and Asp401, Glu458, and Asp542 in T4 Gp17, respectively (Figures 4 and 5) $[23,57]$. These three sites constitute a metal binding cluster in the nuclease domain, which is necessary for large subunit nuclease activities [56]. Metal ions can maintain the structure of the active center of the enzyme molecule and the correct structure of the complex formed by the active center and the substrate. Different viruses have different preferences for divalent cations. For example, HCMV UL89 requires Mn 2+ [57,61], HSV-1 UL15 requires Mg2+ [50], and T4 Gp17 nuclease also requires Mg2+ as a prosthetic group [66,77]. Interestingly, in vitro experiments revealed that pUL15 and its homologous proteins showed nonsequence-specific nuclease activity [50].

It is worth mentioning that in HSV-1 mutants, which lack the 400-420 amino acids between the ATPase and nuclease domains in pUL15, the results showed that the DNA cleavage is slightly defective but the DNA packaging efficiency is greatly reduced [22]. In the T4 phage, the ATPase domain and the nuclease domain are connected by a "hinge". A study has shown that ATPase and nuclease activity can proceed normally when the two domains are expressed alone; however, DNA transfer activity is completely lost [77]. These results indicate that the ATPase and nuclease domains of pUL15 are in different regions of the protein, respectively, but the region between the two domains also plays an important role in the packaging of viral DNA.

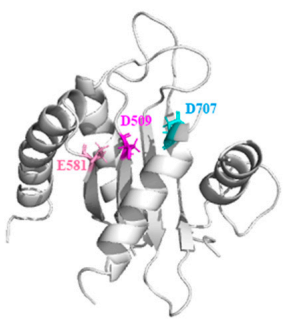

HSV-1 UL15

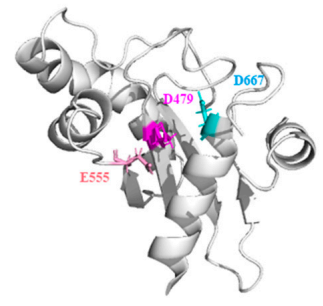

EBV BGRF1/BDRF1

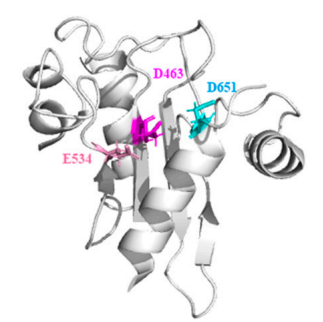

HCMV UL89

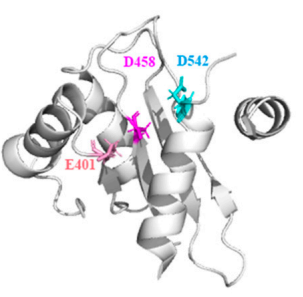

T4 Gp17

Figure 5. Comparison of the terminase large subunit active site region with those of HSV-1 pUL15, HCMV pUL89C, EBV BGRF1/BDRF1, and T4 Gp17, showing conserved features and structural variations. The conservative residues of the active site were marked. The protein structure models were produced using the I-TASSER server. 


\section{Three Models of the Terminase Complex Entering the Nucleus}

\subsection{Nuclear Import of Viral Protein}

Studies have shown that the entry of the majority of viral proteins into the cell nucleus requires the help of a cellular nuclear transport mechanism [78-81]. The nuclear localization signal (NLS) of the cargo protein interacts with the importins in the cytoplasm to form a cargo-importin complex that eventually enters the nucleus through the nuclear pore complex (NPC) on the nuclear membrane [82,83]. Cargo proteins can interact directly with importin $\alpha$ or be mediated by transporter $\beta$ and snurportin (SNP) [84-87].

The classic NLSs are generally divided into two types: monopartite and bipartite NLSs. Monopartite NLS is a short peptide, composed of four to eight amino acids rich in basic amino acids, and generally contains four or more Arg and/or Lys. Both ends of monopartite NLS are usually acidic amino acids or Pro or Gly, and the core sequence is expressed as (K/R) X (K/R). The bipartite NLSs are generally composed of two clusters of basic amino acid residues, which are separated by 10-12 nonconservative amino acid residues. The core sequence is represented as $R / K(X) 10-12$ RRKK $[88,89]$.

\subsection{NLS of the Terminase Large Subunit Mediates HSV-1 Terminase Complex Entry into the Nucleus}

In HSV-1-infected cells, pUL15, pUL28, and pUL33 initially form a complex in the cytoplasm and enter the nucleus at the late stage of infection [20,34,35]. In transiently transfected cells, HSV-1 pUL15 displays nuclear localization when it is expressed alone, while pUL28 and pUL33 remain in the cytoplasm. However, pUL28 and pUL33 can enter the nucleus when coexpressed with pUL15 [90], suggesting an interaction among the three proteins and pUL15 plays an important role in the localization of pUL28 and pUL33 in the nucleus. Further analysis indicated that HSV-1 pUL15 contained a classic NLS at amino acids 183-189 (PKKRAKV). Mutants lacking a pUL15 NLS region will localize exclusively in the cytoplasm. The pUL15/pUL28/pUL33 complex also exclusively localizes to the cytoplasm of cells infected with a mutant virus lacking the pUL15 NLS [35]. These data indicate that pUL15 NLS is necessary for the nuclear localization of pUL15 and the terminase complex. In eukaryotic cells, NLS can bind to nuclear transport receptors, allowing NLS-containing proteins or their complexes to enter the nucleus through NPCs [91,92].

\subsection{NLS of the Terminase Small Subunit Mediate Terminase Complex Entry into the Nucleus}

Biological analysis of the HSV-1 pUL15 NLS showed that the strong NLS in pUL15 gives pUL15 the ability to enter the cell nucleus independently. However, this presentation is only in the $\alpha$-herpesvirus and not in the $\beta$ - and $\gamma$-herpesviruses (Figure 6) [88,89].

In some viruses, strong NLSs are detected in other terminase subunits instead of the NLS in the pUL15 homolog proteins [93]. As with the $\beta$-subfamily HCMV, pUL89 was exclusively cytoplasmic when expressed alone. This finding is consistent with the results of a bioinformatics analysis showing that there is no strong NLS in the pUL89 amino acid sequence. However, the percentage of cells with pUL89 nuclear staining increased to $26 \%$ in the presence of terminase small subunit pUL56, which contains NLSs at amino acids 816-827 (RRVRATRKRPRR), and to $80 \%$ when all three subunits (pUL89, pUL56, and pUL51) are present $[93,94]$. Studies have shown that pUL56 is able to enter the nucleus independently, and its nuclear transfer activity is mediated by the NLS-importin pathway [93].

\subsection{Holoenzyme Mediates Terminase Complex Entry into the Nucleus}

The terminase subunits of other viruses, such as Proboscivirus and Roseolovirus, do not possess strong NLSs that allow each protein to enter the nucleus independently, but they can be transported into the nucleus in the presence of the tripartite terminase complex [91]. Some researchers hypothesize that there may be a part of the NLS in each subunit of the terminase complex in the $\gamma$-herpesviruses. When all subunits form a complex, the complete NLS is activated [91]. 


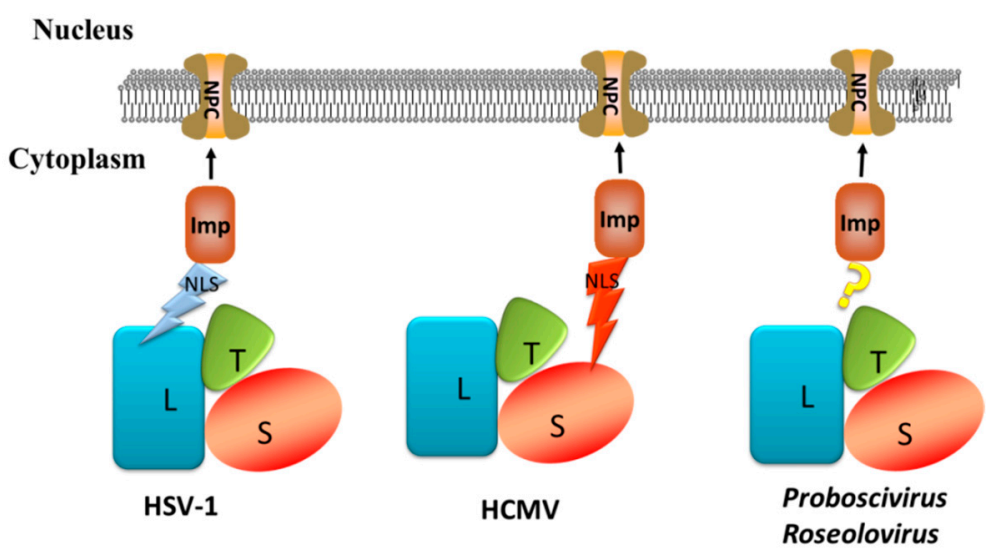

Figure 6. Schematic diagram of terminase nuclear transport modes for different types of viruses. $\mathrm{L}$ represents terminase large subunit, $\mathrm{S}$ represents terminase small subunit, and $\mathrm{T}$ represents terminase third subunit. Terminase binds to the importins and enters the nucleus through the nuclear pore complex (NPC).

\section{Interaction between the Terminase Large Subunit and Other Viral Proteins}

In herpesviruses, three subunits of terminase form a complex through their interactions which is significant for their stability in cells. In HCMV, after transfection of cells with HCMV bacterial artificial chromosome (BAC) lacking UL51, UL56, or UL89 open reading frames (ORFs) in the cells, respectively, the expression levels of the remaining terminase subunits will be decreased [95]. In addition, pUL51 stabilizes pUL56 and pUL89 expression levels and enhances pUL56-pUL89 interaction [96]. This property is not limited to HCMV pUL51 but also applies to other herpesviruses. According to reports, the same phenomenon is also present in HSV-1 pUL15, pUL28, and pUL33, and the terminase subunits are also stabilized with each other $[97,98]$. In HSV-1, pUL15 interacts mainly with the C-terminus of the pUL28, and the interaction between pUL33 and pUL15 is mediated by pUL28. The interaction between pUL33 and pUL28 enhances the interaction between pUL28-pUL33 and pUL15 [98,99].

The portal protein is embedded in the surface of the capsid and forms a channel structure that mediates DNA entry into the shell. The portal interacts with the terminase large subunit and is a docking site for the terminase complex on the capsid [100]. A recent study showed that there is a novel fivefold symmetrical assembly between the portal protein and the portal-vertex-associated tegument (PVAT) in HSV-1, and each subunit of the pentamer has a well-resolved two-helix coiled coil extends vector [101]. Since HSV-1 pUL33 is predicted to be largely $\alpha$-helical in structure [21], there is the possibility that this pentamer is the third subunit of the terminase, pUL33. This assumes that the terminase interaction at the fivefold symmetrical portal vertex is achieved by the third subunit pUL33.

\section{Antiviral Inhibitors Targeting the Terminase Large Subunit}

\subsection{Antiviral Drugs Targeting Herpesviruses}

Herpesvirus is highly transmitted in nature and has been gradually recognized by humans as a virus related to human diseases [102]. The World Health Organization (WHO) reports that approximately $90 \%$ of the world's population is infected with the herpesvirus, and at least nine herpesviruses can infect humans $[102,103]$. Many drugs that inhibit the replication of herpesvirus target viral DNA polymerase [104-108]. Since these antiviral drugs share a common goal, the incidence of cross-resistance should also be considered [109]. Long-term use of these drugs may lead to the emergence of drug-resistant strains [110,111]. In addition, due to the presence of blood toxicity and nephrotoxicity in some drugs, they may not be a good choice for pregnant women [112,113]. Considering these issues, it is necessary to explore new antiviral drugs and constantly search for new and highly effective antiviral targets. The DNA packaging process of herpesvirus does not have a 
counterpart in eukaryocyte cells. The development of drugs targeting the DNA packaging process of herpesvirus is safer and more reliable, and the terminase is a good target. So far, many drugs that target herpesvirus terminase are against HCMV.

\subsection{Small Molecular Inhibitors Targeting the HCMV Terminase Large Subunit}

Currently, the three main drugs used for the treatment of HCMV (ganciclovir, cidofovir, and foscarnet) target the DNA polymerase pUL54 [106,107]. With the emergence of cross-resistance of antiviral drugs, there is a need to continuously develop new antiviral drugs. The benzimidazole D-ribonucleoside BDCRB is a potent inhibitor of HCMV replication $[114,115]$. BDCRB is a nucleoside analog that can inhibit the ATPase activity of the terminase small subunit pUL56, while a high concentration of BDCRB can partially inhibit the nuclease activity of UL89 [76,116]. Two resistant HCMV strains were analyzed and found to have resistance mutations in pUL89 (specifically, D344E and A355T) and pUL56 (specifically, Q204R) [117]. The antiviral effect of BDCRB may be achieved by interfering with the binding of the terminase to DNA. This drug may also inhibit the formation of the terminase structure (i.e., the drug will inhibit the interaction between pUL89 and pUL56). BAY 38-4766 is a nonnucleoside inhibitor for the cleavage and packaging of the HCMV genome. Sequence analyses of HCMV strains that are resistant to BAY 38-4766 indicate that pUL89 and pUL104 are likely targets [118]. Wang et al. found that hydroxypyridonecarboxylic acids (HPCAs) feature a chelating motif that interacts with pUL89 in an Mn2+-dependent manner at the active site, prevents pUL89-C endonuclease activity, and inhibits HCMV replication and genome cleavage [119]. Another compound, GW275175X, is a derivative of D-ribopyranose of BDCRB. It was found that the corresponding mutation, pUL89 D344E amino acid substitution, also appeared in the strain resistant to this drug [120]. It is speculated that its antiviral mechanism is similar to that of BDCRB.

There are also some drugs that target the terminase small subunit. Recently, the terminase inhibitor letermovir has been approved for the prevention of HCMV infection caused by hematopoietic stem cell metastasis. A recent Phase III trial showed that the use of letermovir can significantly reduce the risk of HCMV infection [121]. Letermovir inhibits the packaging of viral DNA into the capsid [122]. Analysis of HCMV strains with a high level of resistance to letermovir revealed that several mutations occurred in the terminase subunit pUL56 (V236M, L241P, C325Y, R369M/G/S) [123]. In addition, there is no bone marrow toxicity or nephrotoxicity in the use of letermovir [121].

\section{Conclusions}

The replication process of herpesviruses includes adsorption, penetration, shelling, biosynthesis, assembly, maturation, and release. The assembly is a virus-specific process that can be used as an antiviral drug target. Studies have shown that the packaging process of dsDNA viruses is mainly accomplished by pUL6, terminase complex, pUL17, pUL25, and pUL32 or their homologs $[16,18,124,125]$.

The terminase complex generally consists of a large subunit, a small subunit, and a third subunit. The large subunits possess two conserved nucleotide-binding motifs-Walker A and Walker B motifs. These two motifs have ATPase activity and allow the terminase large subunit to hydrolyze ATP, providing energy for genome translocation. Studies have shown that the conserved Walker motifs of the terminase large subunit have an important influence on DNA transfer and virus replication in HSV-1and lambda phage $[53,126]$. In addition, the terminase large subunit possesses nuclease activity, ensuring that tandem genomes are cleaved and a complete unit genome is inserted into each viral procapsid. The ATPase and nuclease activities of the terminase large subunit are essential functional enzymatic activities for the virus genome packaging process [48,65,127].

The nucleocapsid assembly process of the herpesvirus occurs mainly in the nucleus, so the process of transporting terminase complex into the nucleus is necessary. The terminase is a protein complex molecule larger than $200 \mathrm{kDa}$, and its nuclear entry depends on the active transport of the system $[23,128]$. The protein that enters the nucleus by active transport must have a special signal in its 
sequence, known as NLS. The way that entry into the nucleus occurs is between different herpesvirus terminases. The terminase large subunit pUL15 of HSV-1 and the terminase small subunit pUL56 of HCMV all contain NLS, but the presence of NLS is not detected in the terminase of some viruses, such as $\gamma$-herpesvirus and some $\beta$-herpesviruses [91]. The nuclear import mechanisms of terminase should be further studied.

Notably, the viral DNA encapsidation mechanism is not present in mammalian cells, so the proteins involved in this process show promise as targets for the development of antiviral drugs, which are relatively safe and reliable. Studies have reported that some DNA packaging inhibitors of the herpesvirus specifically target HCMV pUL89 and pUL56 [119,123,129,130]. These findings will be helpful for the prevention and treatment of herpesvirus.

Author Contributions: L.Y. and Q.Y. contributed to the design of the article; M.W., R.J., S.C., D.Z., M.L. Y.W., X.Z., S.Z., and Y.L. all provided ideas contributing to the conception of this article; Y.Y., L.Z., and X.C. helped draw pictures; and A.C. modified the article.

Funding: This work was supported by the National Natural Science Foundation of China (31402220), China Agricultural Research System (CARS-42-17), Sichuan Veterinary Medicine and Drug Innovation Group of China Agricultural Research System (CARS-SVDIP), and Special Fund for the Key Laboratory of Animal Disease and Human Health of Sichuan Province (2016JPT0004).

Conflicts of Interest: The authors have no conflicts of interest to declare.

\section{References}

1. King, A.M.Q.; Lefkowitz, E.J.; Mushegian, A.R.; Adams, M.J.; Dutilh, B.E.; Gorbalenya, A.E.; Harrach, B.; Harrison, R.L.; Junglen, S.; Knowles, N.J.; et al. Changes to taxonomy and the International Code of Virus Classification and Nomenclature ratified by the International Committee on Taxonomy of Viruses (2018). Arch. Virol. 2018, 162, 2505-2538. [CrossRef] [PubMed]

2. Mcgeoch, D.J.; Rixon, F.J.; Davison, A.J. Topics in herpesvirus genomics and evolution. Virus Res. 2006, 117, 90-104. [CrossRef] [PubMed]

3. Roizman, B.; Carmichael, L.E.; Deinhardt, F.; de-The, G.; Nahmias, A.J.; Plowright, W.; Rapp, F.; Sheldrick, P.; Takahashi, M.; Wolf, K. Herpesviridae. Definition, provisional nomenclature, and taxonomy. The Herpesvirus Study Group, the International Committee on Taxonomy of Viruses. Intervirology 1981, 16, 201-217. [CrossRef] [PubMed]

4. Pellett, P.E.; Roizman, B. The Family Herpesviridae: A Brief Introduction; Lippincott Williams \& Wilkins: Philadelphia, PA, USA, 2007; pp. 2479-2499.

5. Arvin, A.; Campadelli-Fiume, G.; Mocarski, E.; Moore, P.S.; Roizman, B.; Whitley, R.; Yamanishi, K. Comparative virion structures of human herpesviruses. In Human Herpesviruses: Biology, Therapy, and Immunoprophylaxis; Cambridge University Press: Cambridge, UK, 2007; pp. 2-9.

6. Zhou, Z.H.; Chen, D.H.; Jakana, J.; Rixon, F.J.; Chiu, W. Visualization of tegument-capsid interactions and DNA in intact herpes simplex virus type 1 virions. J. Virol. 1999, 73, 3210-3218. [PubMed]

7. Roizman, B.; Furlong, D. The Replication of Herpesviruses; Springer: New York, NY, USA, 1974.

8. Heldwein, E.E.; Lou, H.; Bender, F.C.; Cohen, G.H.; Eisenberg, R.J.; Harrison, S.C. Crystal structure of glycoprotein B from herpes simplex virus 1. Science 2006, 313, 217-220. [CrossRef] [PubMed]

9. Johnson, D.C.; Baines, J.D. Herpesviruses remodel host membranes for virus egress. Nat. Rev. Microbiol. 2011, 9, 382. [CrossRef] [PubMed]

10. Liashkovich, I.; Hafezi, W.; Kühn, J.M.; Oberleithner, H.; Shahin, V. Nuclear delivery mechanism of herpes simplex virus type 1 genome. J. Mol. Recognit. 2011, 24, 414-421. [CrossRef] [PubMed]

11. Enquist, L.W.; Husak, P.J.; Banfield, B.W.; Smith, G.A. Infection and spread of alphaherpesviruses in the nervous system. Adv. Virus Res. 1998, 51, 237-347. [PubMed]

12. Epstein, M.A. Observations on the mode of release of herpes virus from infected HeLa cells. J. Cell Biol. 1962, 12, 589-597. [CrossRef] [PubMed]

13. White, C.A.; Stow, N.D.; Patel, A.H.; Hughes, M.; Preston, V.G. Herpes Simplex Virus Type 1 Portal Protein UL6 Interacts with the Putative Terminase Subunits UL15 and UL28. J. Virol. 2003, 77, 6351-6358. [CrossRef] [PubMed] 
14. Addison, C.; Rixon, F.J.; Preston, V.G. Herpes simplex virus type 1 UL28 gene product is important for the formation of mature capsids. J. Gen. Virol. 1990, 71 Pt 10, 2377-2384. [CrossRef]

15. Alkobaisi, M.F.; Rixon, F.J.; Mcdougall, I.; Preston, V.G. The herpes simplex virus UL33 gene product is required for the assembly of full capsids. Virology 1991, 180, 380-388. [CrossRef]

16. Lamberti, C.; Weller, S.K. The herpes simplex virus type 1 cleavage/packaging protein, UL32, is involved in efficient localization of capsids to replication compartments. J. Virol. 1998, 72, 2463-2473. [PubMed]

17. Mcnab, A.R.; Desai, P.; Person, S.; Roof, L.L.; Thomsen, D.R.; Newcomb, W.W.; Brown, J.C.; Homa, F.L. The Product of the Herpes Simplex Virus Type 1 UL25 Gene Is Required for Encapsidation but Not for Cleavage of Replicated Viral DNA. J. Virol. 1998, 72, 1060-1070. [PubMed]

18. Salmon, B.; Cunningham, C.; Davison, A.J.; Harris, W.J.; Baines, J.D. The Herpes Simplex Virus Type 1 UL17 Gene Encodes Virion Tegument Proteins That Are Required for Cleavage and Packaging of Viral DNA. J. Virol. 1998, 72, 3779-3788. [PubMed]

19. Albright, B.S.; Kosinski, A.; Szczepaniak, R.; Cook, E.A.; Stow, N.D.; Conway, J.F.; Weller, S.K. The putative herpes simplex virus 1 chaperone protein UL32 modulates disulfide bond formation during infection. J. Virol. 2015, 89, 443-453. [CrossRef] [PubMed]

20. Beard, P.M.; Taus, N.S.; Baines, J.D. DNA cleavage and packaging proteins encoded by genes U(L)28, U(L)15, and $\mathrm{U}(\mathrm{L}) 33$ of herpes simplex virus type 1 form a complex in infected cells. J. Virol. 2002, 76, 4785-4791. [CrossRef] [PubMed]

21. Beilstein, F.; Higgs, M.R.; Stow, N.D. Mutational Analysis of the Herpes Simplex Virus Type 1 DNA Packaging Protein UL33. J. Virol. 2009, 83, 8938-8945. [CrossRef] [PubMed]

22. Yang, K.; Wills, E.G.; Baines, J.D. A mutation in UL15 of herpes simplex virus 1 that reduces packaging of cleaved genomes. J. Virol. 2011, 85, 11972-11980. [CrossRef] [PubMed]

23. Heming, J.D.; Huffman, J.B.; Jones, L.M.; Homa, F.L. Isolation and characterization of the herpes simplex virus 1 terminase complex. J. Virol. 2014, 88, 225-236. [CrossRef] [PubMed]

24. Casjens, S.R. The DNA-packaging nanomotor of tailed bacteriophages. Nat. Rev. Microbiol. 2011, 9, 647-657. [CrossRef] [PubMed]

25. Rao, V.B.; Feiss, M. The Bacteriophage DNA Packaging Motor. Annu. Rev. Genet. 2008, 42, 647-681. [CrossRef] [PubMed]

26. Guo, P.; Zhao, Z.; Haak, J.; Wang, S.; Wu, D.; Meng, B.; Weitao, T. Common mechanisms of DNA translocation motors in bacteria and viruses using one-way revolution mechanism without rotation. Biotechnol. Adv. 2014, 32, 853-872. [CrossRef] [PubMed]

27. McNulty, R.; Lokareddy, R.K.; Roy, A.; Yang, Y.; Lander, G.C.; Heck, A.J.R.; Johnson, J.E.; Cingolani, G. Architecture of the Complex Formed by Large and Small Terminase Subunits from Bacteriophage P22. J. Mol. Biol. 2015, 427, 3285-3299. [CrossRef] [PubMed]

28. Heming, J.D.; Conway, J.F.; Homa, F.L. Herpesvirus Capsid Assembly and DNA Packaging. Adv. Anat. Embryol. Cell Biol. 2017, 223, 119-142. [PubMed]

29. Gibson, W.; Roizman, B. Proteins specified by herpes simplex virus. 8. Characterization and composition of multiple capsid forms of subtypes 1 and 2. J. Virol. 1972, 10, 1044-1052. [PubMed]

30. Newcomb, W.W.; Homa, F.L.; Thomsen, D.R.; Booy, F.P.; Trus, B.L.; Steven, A.C.; Spencer, J.V.; Brown, J.C. Assembly of the Herpes Simplex Virus Capsid: Characterization of Intermediates Observed During Cell-free Capsid Formation. J. Mol. Biol. 1996, 263, 432-446. [CrossRef] [PubMed]

31. Rixon, F.J.; Mcnab, D. Packaging-competent capsids of a herpes simplex virus temperature-sensitive mutant have properties similar to those of in vitro-assembled procapsids. J. Virol. 1999, 73, 5714-5721. [PubMed]

32. Newcomb, W.W.; Trus, B.L.; Cheng, N.; Steven, A.C.; Sheaffer, A.K.; Tenney, D.J.; Weller, S.K.; Brown, J.C. Isolation of herpes simplex virus procapsids from cells infected with a protease-deficient mutant virus. J. Virol. 2000, 74, 1663-1673. [CrossRef] [PubMed]

33. Newcomb, W.; Homa, F.D.; Trus, B.; Cheng, N.; Steven, A.; Booy, F.; Brown, J. Assembly of the herpes simplex virus procapsid from purified components and identification of small complexes containing the major capsid and scaffolding proteins. J. Virol. 1999, 73, 4239-4250. [PubMed]

34. Higgs, M.R.; Preston, V.G.; Stow, N.D. The UL15 protein of herpes simplex virus type 1 is necessary for the localization of the UL28 and UL33 proteins to viral DNA replication centres. J. Gen. Virol. 2008, 89, 1709-1715. [CrossRef] [PubMed] 
35. Yang, K.; Homa, F.; Baines, J.D. Putative Terminase Subunits of Herpes Simplex Virus 1 Form a Complex in the Cytoplasm and Interact with Portal Protein in the Nucleus. J. Virol. 2007, 81, 6419-6433. [CrossRef] [PubMed]

36. Adelman, K.; Salmon, B.; Baines, J.D. Herpes Simplex Virus DNA Packaging Sequences Adopt Novel Structures that are Specifically Recognized by a Component of the Cleavage and Packaging Machinery. Proc. Natl. Acad. Sci. USA 2001, 98, 3086-3091. [CrossRef] [PubMed]

37. Yang, K.; Dang, X.; Baines, J.D. A domain of Herpes simplex virus pUL33 required to release monomeric viral genomes from cleaved concatameric DNA. J. Virol. 2017, 9, 817-854.

38. Yang, K.; Wills, E.; Baines, J.D. A Herpes Simplex Virus Scaffold Peptide That Binds the Portal Vertex Inhibits Early Steps in Viral Replication. J. Virol. 2013, 87, 6876-6887. [CrossRef] [PubMed]

39. Elizabeth, W.; Luella, S.; Baines, J.D. Herpes simplex virus 1 DNA packaging proteins encoded by UL6, UL15, UL17, UL28, and UL33 are located on the external surface of the viral capsid. J. Virol. 2006, 80, 10894-10899.

40. Dasgupta, A.; Wilson, D.W. ATP depletion blocks herpes simplex virus DNA packaging and capsid maturation. J. Virol. 1999, 73, 2006-2015. [PubMed]

41. Sheaffer, A.K.; Newcomb, W.W.; Gao, M.; Yu, D.; Weller, S.K.; Brown, J.C.; Tenney, D.J. Herpes simplex virus DNA cleavage and packaging proteins associate with the procapsid prior to its maturation. J. Virol. 2001, 75, 687-698. [CrossRef] [PubMed]

42. Hodge, P.D.; Stow, N.D. Effects of mutations within the herpes simplex virus type 1 DNA encapsidation signal on packaging efficiency. J. Virol. 2001, 75, 8977-8986. [CrossRef] [PubMed]

43. Mocarski, E.S.; Roizman, B. Structure and role of the herpes simplex virus DNA termini in inversion, circularization and generation of virion DNA. Cell 1982, 31, 89-97. [CrossRef]

44. Beard, P.M.; Baines, J.D. The DNA cleavage and packaging protein encoded by the UL33 gene of herpes simplex virus 1 associates with capsids. Virology 2004, 324, 475-482. [CrossRef] [PubMed]

45. Taus, N.S.; Baines, J.D. Herpes Simplex Virus 1 DNA Cleavage/Packaging: The U L 28 Gene Encodes a Minor Component of B Capsids. Virology 1998, 252, 443-449. [CrossRef] [PubMed]

46. Yu, D.; Weller, S.K. Herpes simplex virus type 1 cleavage and packaging proteins UL15 and UL28 are associated with B but not C capsids during packaging. J. Virol. 1998, 72, 7428-7439. [PubMed]

47. Baines, J.D.; Cunningham, C.; Nalwanga, D.; Davison, A. The U(L)15 gene of herpes simplex virus type 1 contains within its second exon a novel open reading frame that is translated in frame with the U(L)15 gene product. J. Virol. 1997, 71, 2666-2673. [PubMed]

48. Przech, A.J.; Yu, D.; Weller, S.K. Point mutations in exon I of the herpes simplex virus putative terminase subunit, UL15, indicate that the most conserved residues are essential for cleavage and packaging. J. Virol. 2003, 77, 9613-9621. [CrossRef] [PubMed]

49. Salmon, B.; Nalwanga, D.; Fan, Y.; Baines, J.D. Proteolytic cleavage of the amino terminus of the U(L)15 gene product of herpes simplex virus type 1 is coupled with maturation of viral DNA into unit-length genomes. J. Virol. 1999, 73, 8338-8348. [PubMed]

50. Selvarajan Sigamani, S.; Zhao, H.; Kamau, Y.N.; Baines, J.D.; Tang, L. The Structure of the Herpes Simplex Virus DNA-Packaging Terminase pUL15 Nuclease Domain Suggests an Evolutionary Lineage among Eukaryotic and Prokaryotic Viruses. J. Virol. 2013, 87, 7140-7148. [CrossRef] [PubMed]

51. Xu, R.; Jenkins, H.T.; Chechik, M.; Blagova, E.V.; Lopatina, A.; Klimuk, E.; Minakhin, L.; Severinov, K.; Greive, S.J.; Antson, A.A. Viral genome packaging terminase cleaves DNA using the canonical RuvC-like two-metal catalysis mechanism. Nucleic Acids Res. 2017, 45, 3580-3590. [CrossRef] [PubMed]

52. Zhao, H.; Lin, Z.; Lynn, A.Y.; Varnado, B.; Beutler, J.A.; Murelli, R.P.; Le Grice, S.F.J.; Tang, L. Two distinct modes of metal ion binding in the nuclease active site of a viral DNA-packaging terminase: Insight into the two-metal-ion catalytic mechanism. Nucleic Acids Res. 2015, 43, 11003-11016. [CrossRef] [PubMed]

53. DelToro, D.; Ortiz, D.; Ordyan, M.; Sippy, J.; Oh, C.S.; Keller, N.; Feiss, M.; Catalano, C.E.; Smith, D.E. Walker-A Motif Acts to Coordinate ATP Hydrolysis with Motor Output in Viral DNA Packaging. J. Mol. Biol. 2016, 428, 2709-2729. [CrossRef] [PubMed]

54. Mitchell, M.S.; Rao, V.B. Functional analysis of the bacteriophage T4 DNA-packaging ATPase motor. J. Biol. Chem. 2006, 281, 518-527. [CrossRef] [PubMed]

55. Yu, D.; Weller, S. Genetic analysis of the UL 15 gene locus for the putative terminase of herpes simplex virus type 1. Virology 1998, 243, 32-44. [CrossRef] [PubMed] 
56. Yang, W. Nucleases: Diversity of structure, function and mechanism. Q. Rev. Biophys. 2011, 44, 1-93. [CrossRef] [PubMed]

57. Nadal, M.; Mas, P.J.; Blanco, A.G.; Arnan, C.; Solà, M.; Hart, D.J.; Coll, M. Structure and inhibition of herpesvirus DNA packaging terminase nuclease domain. Proc. Natl. Acad. Sci. USA 2010, 107, 16078-16083. [CrossRef] [PubMed]

58. Ghoshkumar, M.; Alam, T.I.; Draper, B.; Stack, J.D.; Rao, V.B. Regulation by interdomain communication of a headful packaging nuclease from bacteriophage T4. Nucleic Acids Res. 2011, 39, 2742-2755. [CrossRef] [PubMed]

59. Yeo, A.; Feiss, M. Specific interaction of terminase, the DNA packaging enzyme of bacteriophage lambda, with the portal protein of the prohead. J. Mol. Biol. 1995, 245, 141-150. [CrossRef] [PubMed]

60. Morita, M.; Fujisawa, H.T.M. Structural and functional domains of the large subunit of the bacteriophage $\mathrm{t} 3$ dna packaging enzyme-Importance of the c-terminal region in prohead binding. J. Mol. Biol. 1995, 245, 635-644. [CrossRef] [PubMed]

61. Couvreux, A.; Hantz, S.; Marquant, R.; Champier, G.; Alain, S.; Morellet, N.; Bouaziz, S. Insight into the structure of the pUL89 C-terminal domain of the human cytomegalovirus terminase complex. Proteins Struct. Funct. Bioinform. 2010, 78, 1520-1530. [CrossRef] [PubMed]

62. Roy, A.; Cingolani, G. Structure of p22 headful packaging nuclease. J. Biol. Chem. 2012, 287, $28196-28205$. [CrossRef] [PubMed]

63. Smits, C.; Chechik, M.; Kovalevskiy, O.V.; Shevtsov, M.B.; Foster, A.W.; Alonso, J.C.; Antson, A.A. Structural basis for the nuclease activity of a bacteriophage large terminase. EMBO Rep. 2009, 10, 592-598. [CrossRef] [PubMed]

64. Nowotny, M.; Gaidamakov, S.A.; Ghirlando, R.; Cerritelli, S.M.; Crouch, R.J.; Yang, W. Structure of Human RNase H1 Complexed with an RNA/DNA Hybrid: Insight into HIV Reverse Transcription. Mol. Cell 2007, 28, 264-276. [CrossRef] [PubMed]

65. Sun, S.; Kondabagil, K.; Draper, B.; Alam, T.I.; Bowman, V.D.; Zhang, Z.; Hegde, S.; Fokine, A.; Rossmann, M.G.; Rao, V.B. The structure of the phage T4 DNA packaging motor suggests a mechanism dependent on electrostatic forces. Cell 2008, 135, 1251-1262. [CrossRef] [PubMed]

66. Black, L.W.; Rao, V.B. Structure, assembly, and DNA packaging of the bacteriophage T4 head. Adv. Virus Res. 2012, 82, 119-153. [PubMed]

67. Bottoms, C.A.; Smith, P.E.; Tanner, J.J. A structurally conserved water molecule in Rossmann dinucleotide-binding domains. Protein Sci. 2010, 11, 2125-2137. [CrossRef] [PubMed]

68. Zhu, H.; Li, H.; Han, Z.; Shao, Y.; Wang, Y.; Kong, X. Identification of a spliced gene from duck enteritis virus encoding a protein homologous to UL15 of herpes simplex virus 1. Virol. J. 2011, 8, 156. [CrossRef] [PubMed]

69. Walker, J.E.; Saraste, M.; Runswick, M.J.; Gay, N.J. Distantly related sequences in the alpha- and beta-subunits of ATP synthase, myosin, kinases and other ATP-requiring enzymes and a common nucleotide binding fold. EMBO J. 1982, 1, 945-951. [CrossRef] [PubMed]

70. Draper, B.; Rao, V.B. An ATP hydrolysis sensor in the DNA packaging motor from bacteriophage T4 suggests an inchworm-type translocation mechanism. J. Mol. Biol. 2007, 369, 79-94. [CrossRef] [PubMed]

71. Leffers, G.; Rao, V.B. Biochemical characterization of an ATPase activity associated with the large packaging subunit gp17 from bacteriophage T4. J. Biol. Chem. 2000, 275, 37127-37136. [CrossRef] [PubMed]

72. Baumann, R.G.; Black, L.W. Isolation and Characterization of T4 Bacteriophage gp17 Terminase, a Large Subunit Multimer with Enhanced ATPase Activity. J. Biol. Chem. 2003, 278, 4618-4627. [CrossRef] [PubMed]

73. Franklin, J.L.; Haseltine, D.; Davenport, L.; Mosig, G. The largest (70 kDa) product of the bacteriophage T4 DNA terminase gene 17 binds to single-stranded DNA segments and digests them towards junctions with double-stranded DNA. J. Mol. Biol. 1998, 277, 541-557. [CrossRef] [PubMed]

74. Champier, G.; Hantz, S.; Couvreux, A.; Stuppfler, S.; Mazeron, M.C.; Bouaziz, S.; Denis, F.; Alain, S. New functional domains of human cytomegalovirus pUL89 predicted by sequence analysis and three-dimensional modelling of the catalytic site DEXDc. Antivir. Ther. 2007, 12, 217-232. [PubMed]

75. Hwang, J.S.; Bogner, E. ATPase activity of the terminase subunit pUL56 of human cytomegalovirus. J. Biol. Chem. 2002, 277, 6943-6948. [CrossRef] [PubMed]

76. Scholz, B.; Rechter, S.; Drach, J.C.; Townsend, L.B.; Bogner, E. Identification of the ATP-binding site in the terminase subunit pUL56 of human cytomegalovirus. Nucleic Acids Res. 2003, 31, 1426-1433. [CrossRef] [PubMed] 
77. Kanamaru, S.; Kondabagil, K.; Rossmann, M.G.; Rao, V.B. The functional domains of bacteriophage $\mathrm{t} 4$ terminase. J. Biol. Chem. 2004, 279, 40795-40801. [CrossRef] [PubMed]

78. Wang, Y.; Du, W.; Huang, L.; Wei, Y.; Wu, H.; Feng, L.; Liu, C. The Pseudorabies Virus DNA Polymerase Accessory Subunit UL42 Directs Nuclear Transport of the Holoenzyme. Front. Microbiol. 2016, 7, 124. [CrossRef] [PubMed]

79. Nakada, R.; Hirano, H.; Matsuura, Y. Structure of importin- $\alpha$ bound to a non-classical nuclear localization signal of the influenza A virus nucleoprotein. Sci. Rep. 2015, 5, 15055. [CrossRef] [PubMed]

80. Bennett, S.M.; Zhao, L.; Bosard, C.; Imperiale, M.J. Role of a nuclear localization signal on the minor capsid Proteins VP2 and VP3 in BKPyV nuclear entry. Virology 2015, 474, 110-116. [CrossRef] [PubMed]

81. Webel, R.; Solbak, S.M.Ø.; Held, C.; Milbradt, J.; Groß, A.; Eichler, J.; Wittenberg, T.; Jardin, C.; Sticht, H.; Fossen, T. Nuclear import of isoforms of the cytomegalovirus kinase pUL97 is mediated by differential activity of NLS1 and NLS2 both acting through classical importin- $\alpha$ binding. J. Gen. Virol. 2012, 93, 1756-1768. [CrossRef] [PubMed]

82. Marfori, M.; Mynott, A.; Ellis, J.J.; Mehdi, A.M.; Saunders, N.F.W.; Curmi, P.M.; Forwood, J.K.; Bodén, M.; Kobe, B. Molecular basis for specificity of nuclear import and prediction of nuclear localization. Biochim. Biophys. Acta 2011, 1813, 1562-1577. [CrossRef] [PubMed]

83. Cingolani, G.; Petosa, C.; Weis, K.; Muller, C.W. Structure of importin-beta bound to the IBB domain of importin-alpha. Nature 1999, 399, 221-229. [CrossRef] [PubMed]

84. Cingolani, G.; Bednenko, J.; Gillespie, M.T.; Gerace, L. Molecular basis for the recognition of a nonclassical nuclear localization signal by importin beta. Mol. Cell 2002, 10, 1345-1353. [CrossRef]

85. Pumroy, R.A.; Cingolani, G. Diversification of importin- $\alpha$ isoforms in cellular trafficking and disease states. Biochem. J. 2015, 466, 13-28. [CrossRef] [PubMed]

86. Lott, K.; Bhardwaj, A.; Mitrousis, G.; Pante, N.; Cingolani, G. The importin beta binding domain modulates the avidity of importin beta for the nuclear pore complex. J. Biol. Chem. 2010, 285, 13769-13780. [CrossRef] [PubMed]

87. Lott, K.; Cingolani, G. The importin beta binding domain as a master regulator of nucleocytoplasmic transport. Biochim. Biophys. Acta 2011, 1813, 1578-1592. [CrossRef] [PubMed]

88. Fontes, M.R.; Teh, T.; Kobe, B. Structural basis of recognition of monopartite and bipartite nuclear localization sequences by mammalian importin-alpha. J. Mol. Biol. 2000, 297, 1183-1194. [CrossRef] [PubMed]

89. Conti, E.; Uy, M.; Leighton, L.; Blobel, G.; Kuriyan, J. Crystallographic analysis of the recognition of a nuclear localization signal by the nuclear import factor karyopherin alpha. Cell 1998, 94, 193-204. [CrossRef]

90. Koslowski, K.M.; Shaver, P.R.; Ii, J.T.C.; Wilson, T.; Yamanaka, G.; Sheaffer, A.K.; Tenney, D.J.; Pederson, N.E. Physical and Functional Interactions between the Herpes Simplex Virus UL15 and UL28 DNA Cleavage and Packaging Proteins. J. Virol. 1999, 73, 1704-1707. [PubMed]

91. Sankhala, R.S.; Lokareddy, R.K.; Cingolani, G. Divergent Evolution of Nuclear Localization Signal Sequences in Herpesvirus Terminase Subunits. J. Biol. Chem. 2016, 291, 11420-11433. [CrossRef] [PubMed]

92. Shields, J.M.; Yang, V.W. Two Potent Nuclear Localization Signals in the Gut-enriched Krüppel-like Factor Define a Subfamily of Closely Related Krüppel Proteins. J. Biol. Chem. 1997, 272, 18504-18507. [CrossRef] [PubMed]

93. Giesen, K.; Radsak, K.; Bogner, E. The potential terminase subunit of human cytomegalovirus, pUL56, is translocated into the nucleus by its own nuclear localization signal and interacts with importin alpha. J. Gen. Virol. 2000, 81, 2231-2244. [CrossRef] [PubMed]

94. Wang, J.B.; Zhu, Y.; McVoy, M.A.; Parris, D.S. Changes in subcellular localization reveal interactions between human cytomegalovirus terminase subunits. Virol. J. 2012, 9, 315. [CrossRef] [PubMed]

95. Neuber, S.; Wagner, K.; Goldner, T.; Lischka, P.; Steinbrueck, L.; Messerle, M.; Borst, E.M. Mutual Interplay between the Human Cytomegalovirus Terminase Subunits pUL51, pUL56, and pUL89 Promotes Terminase Complex Formation. J. Virol. 2017, 91, e2316-e2384. [CrossRef] [PubMed]

96. Borst, E.M.; Kleine-Albers, J.; Gabaev, I.; Babic, M.; Wagner, K.; Binz, A.; Degenhardt, I.; Kalesse, M.; Jonjic, S.; Bauerfeind, R. The human cytomegalovirus UL51 protein is essential for viral genome cleavage-packaging and interacts with the terminase subunits pUL56 and pUL89. J. Virol. 2013, 87, 1720-1732. [CrossRef] [PubMed] 
97. Jacobson, J.G.; Yang, K.; Baines, J.D.; Homa, F.L. Linker Insertion Mutations in the Herpes Simplex Virus Type 1 UL28 Gene: Effects on UL28 Interaction with UL15 and UL33 and Identification of a Second-Site Mutation in the UL15 Gene That Suppresses a Lethal UL28 Mutation. J. Virol. 2006, 80, 12312-12323. [CrossRef] [PubMed]

98. Yang, K.; Baines, J.D. The putative terminase subunit of herpes simplex virus 1 encoded by UL28 is necessary and sufficient to mediate interaction between pUL15 and pUL33. J. Virol. 2006, 80, 5733-5739. [CrossRef] [PubMed]

99. Yang, K.; Poon, A.P.; Roizman, B.; Baines, J.D. Temperature-Sensitive Mutations in the Putative Herpes Simplex Virus Type 1 Terminase Subunits pUL15 and pUL33 Preclude Viral DNA Cleavage/Packaging and Interaction with pUL28 at the Nonpermissive Temperature. J. Virol. 2008, 82, 487-494. [CrossRef] [PubMed]

100. Lokareddy, R.K.; Sankhala, R.S.; Roy, A.; Afonine, P.V.; Motwani, T.; Teschke, C.M.; Parent, K.N.; Cingolani, G. Portal protein functions akin to a DNA-sensor that couples genome-packaging to icosahedral capsid maturation. Nat. Commun. 2017, 8, 14310. [CrossRef] [PubMed]

101. Mcelwee, M.; Vijayakrishnan, S.; Rixon, F.; Bhella, D. Structure of the herpes simplex virus portal-vertex. PLoS Biol. 2018, 16, e2006191. [CrossRef] [PubMed]

102. Liu, L. Fields Virology, 6th Edition. Clin. Infect. Dis. 2014, 59, 613. [CrossRef]

103. Fujiwara, S.; Matsuda, G.; Imadome, K. Humanized mouse models of epstein-barr virus infection and associated diseases. Pathogens 2013, 2, 153-176. [CrossRef] [PubMed]

104. Beese, L.S.; Steitz, T.A. Structural basis for the 3'-5' exonuclease activity of Escherichia coli DNA polymerase I: A two metal ion mechanism. EMBO J. 1991, 10, 25-33. [CrossRef] [PubMed]

105. Lurain, N.S.; Chou, S. Antiviral drug resistance of human cytomegalovirus. Clin. Microbiol. Rev. 2010, 23, 689-712. [CrossRef] [PubMed]

106. Andrei, G.; Clercq, E.D.; Snoeck, R. Drug Targets in Cytomegalovirus Infection. Infect. Disord. Drug Targets 2009, 9, 201-222. [CrossRef] [PubMed]

107. Biron, K.K. Antiviral drugs for cytomegalovirus diseases. Antivir. Res. 2006, 71, 154-163. [CrossRef] [PubMed]

108. Xiong, X.; Smith, J.L.; Chen, M.S. Effect of incorporation of cidofovir into DNA by human cytomegalovirus DNA polymerase on DNA elongation. Antimicrob. Agents Chemother. 1997, 41, 594-599. [CrossRef] [PubMed]

109. Drew, W.L. Cytomegalovirus resistance testing: Pitfalls and problems for the clinician. Clin. Infect. Dis. 2010, 50, 733-736. [CrossRef] [PubMed]

110. Chou, S. Approach to drug-resistant cytomegalovirus in transplant recipients. Curr. Opin. Infect. Dis. 2015, 28, 293-299. [CrossRef] [PubMed]

111. Chou, S. Antiviral drug resistance in human cytomegalovirus. Transpl. Infect. Dis. 2010, 1, 105-114. [CrossRef]

112. Lea, A.P.; Bryson, H.M. Cidofovir. Drugs 1996, 52, 225-230. [CrossRef] [PubMed]

113. Wagstaff, A.J.; Bryson, H.M. Foscarnet. Drugs 1994, 48, 199-226. [CrossRef] [PubMed]

114. Komazin, G.; Townsend, L.B.; Drach, J.C. Role of a Mutation in Human Cytomegalovirus Gene UL104 in Resistance to Benzimidazole Ribonucleosides. J. Virol. 2004, 78, 710-715. [CrossRef] [PubMed]

115. Zou, R.; Drach, J.C.; Townsend, L.B. Design, synthesis, and antiviral evaluation of 2-substituted 4,5-dichloroand 4,6-dichloro-1-beta-D-ribofuranosylbenzimidazoles as potential agents for human cytomegalovirus infections. J. Med. Chem. 2010, 28, 802-810.

116. Scheffczik, H.; Savva, C.G.W.; Holzenburg, A.; Kolesnikova, L.; Bogner, E. The terminase subunits pUL56 and pUL89 of human cytomegalovirus are DNA-metabolizing proteins with toroidal structure. Nucleic Acids Res. 2002, 30, 1695-1703. [CrossRef] [PubMed]

117. Underwood, M.R.; Harvey, R.J.; Stanat, S.C.; Hemphill, M.L.; Miller, T.; Drach, J.C.; Townsend, L.B.; Biron, K.K. Inhibition of human cytomegalovirus DNA maturation by a benzimidazole ribonucleoside is mediated through the UL89 gene product. J. Virol. 1998, 72, 717-725. [PubMed]

118. Reefschlaeger, J.; Bender, W.; Hallenberger, S.; Weber, O.; Eckenberg, P.; Goldmann, S.; Haerter, M.; Buerger, I.; Trappe, J.; Herrington, J.A.; et al. Novel non-nucleoside inhibitors of cytomegaloviruses (BAY 38-4766): In vitro and in vivo antiviral activity and mechanism of action. J. Antimicrob. Chemother. 2001, 48, 757-767. [CrossRef] [PubMed]

119. Kankanala, J.; Wang, Y.; Geraghty, R.J.; Wang, Z. Hydroxypyridonecarboxylic Acids as Inhibitors of Human Cytomegalovirus pUL89 Endonuclease. Chemmedchem 2018, 13, 1658-1663. [CrossRef] [PubMed] 
120. Underwood, M.R.; Ferris, R.G.; Selleseth, D.W.; Davis, M.G.; Drach, J.C.; Townsend, L.B.; Biron, K.K.; Boyd, F.L. Mechanism of action of the ribopyranoside benzimidazole GW275175X against human cytomegalovirus. Antimicrob. Agents Chemother. 2004, 48, 1647-1651. [CrossRef] [PubMed]

121. Marty, F.M.; Ljungman, P.; Chemaly, R.F.; Maertens, J.; Dadwal, S.S.; Duarte, R.F.; Haider, S.; Ullmann, A.J.; Katayama, Y.; Brown, J. Letermovir Prophylaxis for Cytomegalovirus in Hematopoietic-Cell Transplantation. N. Engl. J. Med. 2017, 377, 2433-2444. [CrossRef] [PubMed]

122. Frange, P.; Leruez-Ville, M. Maribavir, brincidofovir and letermovir: Efficacy and safety of new antiviral drugs for treating cytomegalovirus infections. Méd. Mal. Infect. 2018, 48, 495-502. [CrossRef] [PubMed]

123. Frietsch, J.J.; Michel, D.; Stamminger, T.; Hunstig, F.; Birndt, S.; Schnetzke, U.; Scholl, S.; Hochhaus, A.; Hilgendorf, I. In Vivo Emergence of UL56 C325Y Cytomegalovirus Resistance to Letermovir in a Patient with Acute Myeloid Leukemia after Hematopoietic Cell Transplantation. Mediterr. J. Hematol Infect. Dis. 2019, 11, e2019001. [CrossRef] [PubMed]

124. Rao, V.B.; Feiss, M. Mechanisms of DNA Packaging by Large Double-Stranded DNA Viruses. Annu. Rev. Virol. 2015, 2, 351-378. [CrossRef] [PubMed]

125. Bataille, D.; Epstein, A.L. Herpes simplex virus type 1 replication and recombination. Biochimie 1995, 77, 787-795. [CrossRef]

126. Oliveira, L.; Cuervo, A.P. Direct interaction of the bacteriophage SPP1 packaging ATPase with the portal protein. J. Biol. Chem. 2010, 285, 7366-7373. [CrossRef] [PubMed]

127. Dhar, A.; Feiss, M. Bacteriophage lambda terminase: Alterations of the high-affinity ATPase affect viral DNA packaging. J. Mol. Biol. 2005, 347, 71-80. [CrossRef] [PubMed]

128. Hilbert, B.J.; Hayes, J.A.; Stone, N.P.; Xu, R.G.; Kelch, B.A. The large terminase DNA packaging motor grips DNA with its ATPase domain for cleavage by the flexible nuclease domain. Nucleic Acids Res. 2017, 45, 3591-3605. [CrossRef] [PubMed]

129. Ligat, G.; Cazal, R.; Hantz, S.; Alain, S. The human cytomegalovirus terminase complex as an antiviral target: A close-up view. FEMS Microbiol. Rev. 2018, 42, 137-145. [CrossRef] [PubMed]

130. Gentry, B.G.; Bogner, E.; Drach, J.C. Targeting the terminase: An important step forward in the treatment and prophylaxis of human cytomegalovirus infections. Antivir. Res. 2019, 161, 116-124. [CrossRef] [PubMed]

(C) 2019 by the authors. Licensee MDPI, Basel, Switzerland. This article is an open access article distributed under the terms and conditions of the Creative Commons Attribution (CC BY) license (http:/ / creativecommons.org/licenses/by/4.0/). 